\title{
Adolescents' childbearing dynamics in urban Mozambique: a qualitative analysis in Maputo, Quelimane and Lichinga cities
}

\author{
Mónica Frederico ${ }^{1}$, Carlos Arnaldo ${ }^{1,2}$ \& Hélio Maúngue ${ }^{1}$ \\ ${ }^{1}$ Centro de Estudos Africanos, Universidade Eduardo Mondlane (CEA/UEM) \\ Av. Julius Nyerere, Campus Universitário Principal P.O.Box 1993 \\ Maputo, Mozambique \\ mfrederico45@gmail.com \\ ${ }^{2}$ Centro de Pesquisa em População e Saúde (CEPSA)
}

\begin{abstract}
Despite the implementation of some policies and programs aimed at reducing early and unsafe adolescent sexual activity, adolescent pregnancy and childbearing are major concerns in Mozambique. About $40 \%$ of adolescents aged 15 to 19 are already mothers or pregnant. In light of this high prevalence of early motherhood, this paper aims at discussing socioeconomic and cultural factors influencing adolescent pregnancy and childbearing in urban Mozambique. We use the socioecological perspective framework to analyze focus group discussions data with adolescents, parents and community leaders in the cities of Maputo, Quelimane, and Lichinga. The study reveals that instructions transmitted in the initiation rites, living conditions and the exposure to information and communication technology are the main factors influencing early pregnancy and childbearing among adolescents in Mozambique. Adolescents should be empowered on knowledge about sexuality to prevent early childbearing, and protect them from STIs. Parents should be encouraged to talk openly about sexuality with their children.
\end{abstract}

Keywords: Adolescents, Pregnancy, Mozambique, Socioeconomic-factors, Cultural-factors

\section{Introduction}

Adolescent pregnancy and childbearing are common phenomena in rural and urban areas of Mozambique. Adolescence is a transition period from childhood to adulthood, during which biological changes of puberty that end with full maturity occur (Dehne and Riedner 200I; Gowers 2005, Fatusi and Hindin 2010:499). In this period adolescents develop their sexuality and sexual identity and may engage in unprotected sex that may result in an unplanned and unwanted pregnancy (Arnaldo et al. 20I4; Hindin and Fatusi 2009; Klingberg-Allvin 2007; Blum and NelsonMMari 2004; DHS data 201I; MacPhail and Campbell 200I). It is estimated that $11 \%$ of all births worldwide are born to adolescent girls aged 15 - 19 years old. The majority of these births $(95 \%)$ occur in low- and middle-income countries, and $50 \%$ of them occur in Sub-Saharan Africa (WHO 2014; Chandra-Mouli et al. 2015: 2).

In Mozambique, available Demographic and Health Survey (DHS) data show that about $40 \%$ of adolescents aged 15-19 are already mothers or pregnant and this percentage has not changed in the last 20 years (INE 20I3). Data from the 2007 population census show that $17 \%$ of all enumeratedadolescents aged 12-19 had already been mothers by the time of the census (INE 20I0).

Early pregnancy and childbearing have some health and social consequences for adolescent and her newborn child. Among the consequences are the complications during pregnancy and delivery and the high risk of maternal death; higher than average levels of blood pressure; toxaemia, eclampsia, anaemia, bleeding, obstructed and prolonged labour, low birth weight, premature delivery, as well as a permanent or temporary drop out from school for the pregnant girls (UNFPA 2013; Arnaldo et al. 20I5; Agunbiade et al. 2009; Atuyambe et al. 2005; Oyefara 2009; Pratt and Okigbo 2002; Izugbara 2015; Fatusi and Blum 2008; Vundle et al. 200I).

Studies conducted in some parts of Africa suggest that early pregnancy cannot be explained only by one factor but by the combination of individualiii, interpersonal' ${ }^{\mathrm{v}}$ and community ${ }^{\mathrm{v}}$ factors (Gupta and Mahy 2003; Mumah et al. 2014; Craig and RichterStrudom 1983; Pratt and Okigbo 2002). The educational level of girls Gupta and Mahy (2003), the age of girls sexual debut (Mumah et al. 2014; Machungo 2004); reproductive health knowledge, 
contraceptive knowledge and usage, the sense of decision-making competence regarding themselves and their future (Craig and Richter-Strudom 1983; Macleod and Tracey 2010; Pratt and Okigbo 2002) and the lack of religious commitment (Ochiogu et al. 20II) are among the individual factors. Sex socialization (Craig and Richter-Strudom 1983); poor parental support, marital promise or peer pressure, sexual abuse, and family instability (Ochiogu et al. 20I I) are interpersonal factors. Unfavorable political economy (poverty), poor reproductive health services (Atuyambe et al. 2005); and institutional breakdown (Craig and Richter-Strudom 1983) are community factors.

Additionaly, the exposure to movies (with scenes often around love, sex, and money), television, and myths (Ankomah et al. 20I I); the lack of parent ${ }^{\text {vi }}$ adolescents communication on sexuality and parental disapproval of adolescent sexual behavior (Widman et al. 2014; Guilamo et al. 2012; Miller and Whitaker 200I; Dilorio et al. 1999) also drive adolescents to engage in early sexual intercourse. While, religion, disease prevention, the fear of pregnancy, dropping out school or of bringing shame to the family restrain adolescents from engaging in early sexual activity (Ankomah et al. 20l I).

Several adolescent sexual and reproductive health policies and strategies aimed at reducing the prevalence of early childbearing have been adopted in Mozambique: The Policy and Strategy for Adolescent sexual and reproductive health adopted in 200I; the Adolescent health program, a component of the strategic plan for the health sector (PESS 20 I4-20 I9); and the reproductive health program called Geração $B I Z$ introduced in 1999. These programs were designed to promote sexual and reproductive health for adolescents and youth. Although they have been implemented in Mozambique for more than 15 years, the impact is yet to be seen. Thus, this paper uses qualitative data collected in three cities to discuss sociocultural, economic and Information and communication technology, and peers relations factors influencing adolescent pregnancy and childbearing in urban Mozambique.

\section{Theoretical framework}

This study is based on socioecological perspective (Dahlberg and Krug 2002) which has been used to explain human behavior in several areas including public health. The socioecological model provides a comprehensive framework for understanding and modifying the range of social and environmental factors that contribute to adolescent childbearing. In other words, it provides a comprehensive framework for understanding the multiple and interacting determinants of health behavior (Sallis, Owen and Fisher 2008).

Developed firstly by Urie Bronfenbrenner in 1979, this perspective views behavior as being influenced at multiple levels. That is, the individual characteristics influence the environment which in turn influence the individual behavior (McLeroy and others 1988). This perspective showed a reciprocal causation between the individual and the environment (McLeroy and others 1988; Bronfenbrenner 1994) and was used to understand and explain how sociocultural, economic, and information and communication technology influence adolescents childbearing dynamic in urban areas of Mozambique. In light of this perspective, these factors are part of a set of environmental factors that surround the adolescents. Despite the reciprocity of the causation between the individual and environment, this study emphasized only the environmental influence on the individual considering the evidence from the available data.

\section{Data and methodology}

The study uses data collected in five neighborhoods: George Dimitrov, in Maputo city, Mapiazua and Torone in Quelimane, and Mitava and Ceramica, in Lichinga. The three cities were selected to represent the three major regions in Mozambique with marked sociocultural differences: Maputo in the south, Quelimane in the central region and Lichinga in the northern region. The three regions are different in level of socioeconomic development and access to resources, infrastructures, and services. The Southern Region has the best socio-economic indicators and the Northern Region the worst; the Southern and central regions are predominately patrilineal while the north is predominantly matrilineal.

The fieldwork was conducted between February and March 2013. A total of 17 focus group discussions were conducted in the three study sites, II with adolescents and 6 with parents. In total IIO youth and adolescents ( 57 females and 53 males) and 52 parents (40 mothers and 12 fathers) participated in the focus group discussions.

The number of participants in each focus groups discussion was between 7 and 12. The participants were intentionally selected from the community, and after being explained the study objectives, they gave verbal consent for the interview. The focus group discussions were held separately for males and females for both adolescents and parents. All focus groups discussion were conducted in Portuguese.

The level of education varied among both adolescents and parents with generally more educated (primary and secondary) than those with no education among both adolescents and parents. All 
focus group discussion were recorded and transcribed and qualitative content analysis (Smith 2000) was performed for the identification and interpretation of the major themes (See Arnaldo et al. 20I5, for more details).

Factors influencing early pregnancy among adolescents in Mozambique

Drawing from the literature and from our data we will move to present and discuss the factors influencing early pregnancy among adolescents in Mozambique. The factors are grouped into three categories: sociocultural, economic, and peers, communication and information technology.

\section{Sociocultural factors}

In this section, we present the main categories of sociocultural factors that were mentioned by the participants in focus group discussions. Most sociocultural factors are related to puberty preparation and involve conversation between parents and adolescents and sexual initiation. The data show the influence of social context on adolescent behavior, including cultural variables as socioecological perspective prescribes (Sallis, Owen and Fisher 2008). Bellow, we present some extracts of focus group discussion illustrating the mechanisms through which they influence adolescent pregnancy and childbearing.

\section{Dialogue between parents and adolescents}

The dialogue between parents and their children can be integrated into the discussion about family communication, which is a way of interaction and values transmission in the family. However, some parents are not comfortable to talk with their children about sex, as illustrated by the following extract:

The preparation that I have I had in the initiation rites (...) Our parents practically do not talk about sex with us (...) the experience about dating, sex [relationship], and [pregnancy] prevention we [acquired] through friends and media." (Female participant in adolescent focus group discussion, Maputo City).

There are some gaps in the information flow about sexuality between children and their parents. Adolescents learn from others or media. Obviously, adolescents will learn to adopt the behavior of their friends or what is published by the media. The limitation in the information given by the parents to their children may result from the parents' fear of being misunderstood by the adolescents because providing information about sexuality may mean to the adolescents that their parents are giving freedom to engage in sexual activity.
I have never talked to my mom about it [sexuality and sex]. I do not know; maybe it is because of fear. She only says, because I have gripes, I should not have sex during the menstruation. She says I should stay a week, but talking to her about it [sex], never (Female adolescent in a focus group discussion, Maputo City).

As the adolescent girl referred, she has never talked openly about sexuality and sex with her mother. The mother tried to explain what the daughter should not do during the period of menstruation. However, all procedures related to the period in which she was (transition from childhood to adulthood), the challenges related to the construction of her identity, how to protect herself from pregnancy and STIs, is not explained. The lack of this explanation could contribute to risk behavior that may lead to early pregnancy and childbearing.

It has been mentioned that mothers are afraid of being misunderstood by their daughters. Some fears can be observed in the followings extracts where a mother thinks that talking about sexuality with her daughter at the age of 15 or 16 years it is too early, despite recognizing that nowadays adolescents have access to media and other sources that can provide information about sexuality and dating: I have to talk to her [adolescent] but 15 or 16 years old it is still early. If I talk to her, it would only be about life in general. Now it is early (A mother in focus group discussion, Maputo City).

Even if the parents try to say something to adolescent related to menstruation or sexuality, they do not do it directly. They tend to use language that sometimes adolescents have difficulties to understand. For example, adolescents claim that parents only say to them, not to date, but do not explain when is the right moment to do it.

The dialogue between parents and adolescents require telling the truth using appropriate language that allows adolescent to understand why they have to avoid engaging in the risky sexual activity.

\section{Initiation Rites}

The social status is an important pattern in society with everyone often passing from one status to another during the lifetime. In Quelimane and Lichinga it was common the participants to talk about the specific period in which an adolescent is sent to receive preparation for adulthood. Whereas, in Maputo city, the participants did not mention this. However, despite rituals being considered important for the preparation of individuals for a new status (of the life), some participants showed their disappointment regarding the way this process is being performed:

The nhaco vii I did in my community is different from the one I see now. They say to the girls that no 
man is big, and should not worry about his body size. When I took my daughter there, I asked, after all, if it was about teaching children to have sex? (Mother of focus group, Lichinga).

The extract above shows the influence of cultural values and social norms because the instruction given to the adolescents during the initiation rites is part of values transmitted to girls as a preparation to please a man. The idea that there is no big man for the teen girls can create on them the idea that is not a problem to date, and consequently, have sexual intercourse with an old man. In turn, this may contribute to the current phenomena called catorzinhas, which refer to the relationship between an adolescent girl and an adult man. However, as we know, many of those sexual intercourses are transactional. Consequently, the adolescent girl is not in a condition to discuss safe sex with the use of a condom, exposing herself to the unwanted pregnancy and childbearing. Although mothers recognize the importance of sexual initiation, some are not comfortable with the way their daughters are being initiated, there are rituals where they [namalaka/anamalaka] $]^{\text {viii }}$ teach you [adolescent] how to care for yourself during menstruation, how to take care of your husband, including the sexual intercourse (Fathers focus group discussion, Lichinga).

However, the preparation for sexual intercourse does not occur only for girls, but also for boys. The following extract illustrates this fact:

In the old days, there were initiation rites in which the boys were taken to the bush and stayed there for 2 or 3 weeks up to a month. [There they] were prepared to be a man and were informed to be careful with women [because] they bite. [in that time] to get involved with a woman it was the uncle who used to say, 'now you have grown up' (Father focus group discussion, Quelimane).

Once the boys had been initiated they may try to put into practice what they had learned, and the first person whom they probably would try to contact in those intentions could be an adolescent girl, often equally unprepared to have safe sex. Consequently, both could experience the effects of early pregnancy, childbearing, and sexual infections.

The quotation above seems to highlight how the initiation rites were done in the past. However, despite the long period that adolescents stayed in the woods, they were not taught all things openly. People who were in charge of the initiation rituals taught them using myths, be careful with women [because] they bite, to show the adolescents the need to be prepared to engage in sexual activity. At that time, these kind of myths were powerful because communication and information technology were not as developed and available as they are nowadays. Pornographic material, soap opera, and movies are available and accessible from, even in remote areas; the increasing mobility of adolescents that allow them to be exposed to other cultures reduces the power of local myths and encourages adolescents to engage early in sexual activity often with risky sexual behavior.

\section{Socio-economic factors}

Socio-economic conditions have been explored in many other studies, through analysis of the association between age, place of residence, education and income with knowledge, attitudes, and practices related to pregnancy. A common finding is that poverty, low education, and rural residence are associated with early pregnancy. Although our analysis are based on qualitative data, there are some extracts that illustrate this relationship, especially the lack of financial resource. Since [girls] want money, telephone and a snack, and the young boys do not have taco [money], they are likely to date old men who can provide what they need (adolescent girls focus group discussion, Maputo City).

One of the differentiating factors for the occurrence of pregnancy here in Lichinga is the economic power of families. If a family is economically sustainable, the probability of their children to have early pregnancy is less. Most of the people here are involved in subsistence agriculture. This activity is performed during six months. During this period, they leave their children alone, and when products finish they enter into prostitution unconsciously without knowing what would happen and end up becoming pregnant (Key informant, Lichinga).

Also the low economic conditions of the girls and their families could motivate them to be involved with an old man with stable economic conditions to supply what the teens daily want to do and have. The following extracts illustrate it:

Women [girls] often say, today I do not have soap, and I want to have it. We want to help them [adolescent girls], and they also help us (adolescents boys focus group discussion, Lichinga).

And,

Girls start dating at the age of 9, 10 years, long before menstruation. This [action] occurs because girls want to have money to buy snacks and clothes (Mothers focus group, Quelimane).

Information and communication technology, and peers relations

As human beings, adolescents are influenced by the environment surrounding them. The influence can be positive or negative depending on the environment 
and the capacity to select things that lead to behave as acceptable in the society. It is recognized that information and communication technology (ICT) is a dominant factor that influences the development worldwide, because it links people, and promotes the communication between people located in different continents at the same time. It is also important because ICT facilitates the dissemination of various services worldwide. However, ICT can also have negative influence depending on the kind of information disseminated. For example, pornography, and some passages of soap opera. The same role can be performed by peers or friends when someone engages in certain behavior to fit into the group or change their beliefs or opinion to agree with the opinion of the group: Sometimes we see a lady with the whole body exposed by copying what she sees on TV. It is hard to raise a child, when the television is there, showing everything that should not be shown (Father focus group discussion Maputo City); The children are still young, but they talk about what happens in the soap opera. For example, my grandson says: 'see, there [in the soap opera] they are having sex' (Mothers focus group discussion, Lichinga).

Communication and information technologies are among the factors influencing the behavior of teens on sexual activity and expose them to the risk of an early pregnancy and childbearing.

The peer relationships also influence adolescents to try sexual activity because they hear from friends about the experience and they want to try it. These situations show up the power of influence that peer relationship plays on adolescent's behavior. This power may contribute to early pregnancy and childbearing particularly if the adolescents do not talk about sexuality and reproductive health with their parents.

\section{Discussion}

There are multiple levels of influences (Sallis, Owen and Fisher 2008) for adolescent childbearing. In the context of sexuality, parent-adolescent communication about sex has been seen as a way to reduce risky sexual behavior among adolescents. In Mozambique, however, it is not common for a mother or father to discuss sexual issues with their children. This activity is reserved for another person such as grandmother and aunt or to the initiation rites. This finding is in agreement with Holmam (2014) findings which show that adolescents never had a direct conversation with their parents or stated that they talked to someone other than their parent about sex-related topics. While Andre considers that parents tend to socialize children with more restrictive attitudes about sexuality and as their children's age, parents often find it difficult to switch gears and provide open, and communicative information (Andre et al. 1989).

The absence of communication make adolescents vulnerable to the influenced of friends, peers, and Medias, sometimes negatively. About the lack of communication between young people and adult at the community, Craig and Richter-Strudom (1983) argue that adolescents seem to be forced to drive an "individual bargain" often from the standpoint of ignorance. For the parents to transmit to their children the necessary information that can protect them from early sexual activity and its consequences, the closeness and interaction between adults and adolescents are essential (Craig and Richter-Strudom 1983), because the parent-child relationship and communication is very important in engendering prosocial behaviours in adolescent (Amoteng et al. 2014). In most of the time, communication on sexual health between parents and children is indirect, especially with fathers, and parents may feel that they had had a discussion about a certain topic when the children did not get the message (Saskatchewan Prevention Institute, 201 I). Mothers are uncomfortable to discuss dating, menstruation, sex, and birth control with daughters because of fear that by doing so they are encouraging adolescents to engage in a sexual relationship (Meschke et al. 2000). But, where they are denied acess to adequate information and education on sexuality and related matters, adolescents tend to turn to their peers for 'enlightenment' (Ogunjuyigbe and Adepoju 20।4).

Undoubtedly, in this study, early pregnancy does not result only from the absence of communication, but also from other such as economic factors, which exert significant influence on adolescents. Some adolescent girls resort to transactional sex as a way to have money or things that they want, because the parents do not have enough financial resources to supply them. This practice was also reported by other authors, such as Ochiogu et al. (20I I), Craig and Richter-Strudom (1983), Atuyambe et al. (2005:307), Mumah et al. (20|4), Bagnol and Chambo (2003) and Cole (2007). These authors emphasized the poverty or inadequate financial provision as the predisposition factor to early sexual activity, pregnancy or infection disease, and STIs. This finding suggests that it is necessary to promote inclusive and sustainable economic growth, full and productive employment and decent work with sufficient salary to support them and their families (UNDP N/D). If these conditions are not satisfied, the adolescents may continue to engage in transactional sex.

Culture is recognized to be a factor of cohesion among community members, since they share the 
same patterns of thinking, feeling and acting (Franco 2002; Hofstede 1980). The cultural practice of initiation prepares an individual for the adulthood. As Holm and Bowker (1994) explained rites of passage often help to prepare people for a sense of identity that runs alongside the social status. During the process of passage, the society took individuals by the hand and led them from one social status to other, conducting them to transit the thresholds and holding them for a moment in a position when they were neither in one status or another (Holm and Bowker 1994). However, despite its role, there are same aspects (sexual activity preparation) that the participants, particular mothers, claimed to contribute to the early sexual activity. In the initiation rites the young people are not only told and shown how to behave as adults, and or how to show respect to the elderly, but are also, instructed on how to have sexual intercourse in marriage, how to move during intercourse with the husband, how to wipe and clean his penis after sex, and what to expect from the husband afterwards (Arnfred 20I I).

As our key informants in Lichinga mentioned, nowadays, the initiation process is done once due to the lack of financial resource. In the past, there were three phases of this process. The first was reserved for teaching the child how to behave and show respect to the elderly. The second was for the child who reaches the puberty, and he/she was taught everything related to sexuality and marriage. The third phase was occurring when the girl became pregnant, to teach her how to care for pregnancy and her baby. Nowadays, everything is taught at once, without separation according to age.

Teaching a young adolescent girl how to deal with a man may inform her that she is ready to have sexual intercourse. Thus, it is not surprising, that after initiation, by curiosity adolescents engage in sexual activity because they are stimulated to put in practices what they learned about sexuality and try to get married or to have a partner, which usually results in pregnancy (Osório 2005).

Our results also indicated that poverty, lack of food and soap, exposes adolescents to transactional sex. Since the main task for adolescents is to prepare themselves for the future using the resources offered by parents. In developing countries, like Mozambique, the poverty does not allow parents to supply their children adequately. As we saw from findings, an alternative, adolescents prefer to ask for help from others because they want to buy not only "unnecessary" things but also obtain the resources needed for their schooling and families' needs (Weiner and Kulczycki 20l4).

Information and communication technology, media, and peer relationships influence adolescents on how to deal with sexual activity. As in other parts of the world, Mozambican adolescents are likely to follow what they see from others with whom they interact directly or by television as well as what they see on the internet, which can be positive or negative. The mothers and fathers mentioned that adolescents get pregnant because they wear tight and short clothes which expose the body because they see it on television or in the shops. They also explained that the children saw people kissing each other on television and they comment about it. In our perception, this is part of the natural process resulting from the influence of the environment in which they are exposed. First, they have curiosity as people who are in the period of transition to exercise their sexuality. Second, during this period, the adolescents are more vulnerable to engage in conformist behavior and to feel belonging to a group. This process is particularly true for adolescents living in families without a clear set of guidelines or belief structure.

\section{Conclusion}

This study supports earlier results which found sociocultural, economical, information and communication technology, media, and peers relationships as a set of factors that determine or contribute to early pregnancy and childbearing among adolescents.

Our findings suggest that the reduction of early pregnancy and childbearing require adolescents empowerment in knowledge about sexuality, showing them the disadvantages of early pregnant and how to avoid it. It is also important to make adolescents able to select what is useful and healthy among all things that are available to them. The parents should be empowered and encouraged to talk the truth about sexuality with their children. Otherwise, they will learn from friends and peers and may not get the correct information.

The adolescents, mainly girls, must be empowered about how to delay sexual intercourse, to know that they are the owner of their bodies, to know how negative it is to be exposed to transactional sexual relations. The adolescent boys should know the cost of having a baby at an early age, without any formal or informal income, and they must also be prepared to be the ones who propose the use of condom as the way to prevent early pregnancy, childbearing, and STIs.

The behavior change to reduce and prevent early pregnancy is expected to be maximized when environments and policies support healthful choices; when social norms and social support to healthful choices are strong, and when adolescents are motivated and educated to make those safe choices (Salis et al. 2008). 


\section{Acknowledgments}

Authors gratefully acknowledge the supports and comments from the 2016 Family Demography in Africa and Post-2015 Development Agenda Conference, hosted by Demography and Population Studies and co-sponsored by the NRF CoE in Human Development, NRF Conference Fund and NIHSS.

The authors are also very grateful for Janne Rantala and Naomi Kanno for their contributions and comments to the article.

\section{Authors' contribution:}

All authors contributed significantly to the manuscript. MF and HM collected data and wrote the first manuscript. CA participated in the write up of the second and subsequent version, providing feedback on data analysis and interpretation of results.

\section{References}

Agunbiade, O. M.; Titilayo, A. and Opatola, M 2009. "Pregnancy Stigmatisation and Coping Strategies of Adolescent Mothers in two Yoruba Communities, Southwestern Nigeria." Being a paper presented at the XXVL IUSSP International Population Conference, Marrakech Morocco, September 27-2 October 2009.

Amoateng, A. Y., Kalule-Sabiti, I. and Arkaah, Y. J 2014. "The effect os socio-demographic factors on risky-sexual behaviours of adolescents in the North West province of South Africa". African Population Studies 28 (I): 487-498.

Ankomah, A.; Mamman-Daura, F.; Omoregie, G. and Anyanti, J 201I. "Reasons for delaying or engaging in early sexual initiation among adolescents in Nigeria." Adolescent Health, Medicine and Therapeutics (2): 75-84.

Arnaldo, C., Frederico, M. and Maúngue, H (2015): Níveis, Tendências e Determinantes de Gravidez Precoce entre Adolescentes e Jovens em Moçambique. Maputo: Centro de Estudos Africanos, Universidade Eduardo Mondlane.

Arnfred, S. (20II): Sexuality and Gender Politics in Mozambique: Rethinking Gender in Africa. Sweden: The Nordic Africa Institute, James Currey.

Atuyambe, L.; Mirembe, F.; Johansson, A.; Kirumira, E.K. and Faxelid, E 2005. "Experiences of pregnant adolescents--voices from Wakiso District, Uganda." African Health Science 5, (4): 304-309.

Bagnol, B. and Chamo, E (2003): "Titios" e "catorzinhas": Pesquisa exploratória sobre "sugar daddies" na Zambézia (Quelimane e Pebane). Maputo: DFID/PMG Mozambique.
Blum, R. W and Nelson- MMari, K 2004. "The Health of Young People in a Global Context." Journal of Adolescent Health 35: 402-4I8.

Bronfenbrenner, U. (2 ed) 1994. Ecological Model of Human Development. International Encyclopedia of Education. Oxford: Elsevier.

Chandra-Mouli, V and Svanemyr, J 2015. "Twenty Years After International Conference on Population and Development: Where Are We With Adolescent Sexual and Reproductive Health and Rights?" Journal of Adolescent Health 56, SleS6.

Cole, J (2007): Fresh Contact in Tamatava, Madagascar: Sex, Money, and Intergeneration. In: Cole, Jennifer; Durham, Deborah 2007. Generation and Globalization: Youth, Age, and Family in the New World Economy. Indiana University.

Craig, A. P and Richter-Strudom, L. M. 1983. "Unplanned Pregnancies among Urban Zulu Schoolgirls: Community Research as preparation for Intervention. SA Medical Journal 63, (I2): 452455.

Creswell, J. W (2007): Qualitative Inquiry and Research Design: Choosing Among Five Approaches. Second Edition, New Delhi: SAGE.

Dahlberg L.L. and Krug E. G (2002). Violence - a global public health problem. pp. 3-2I. In: Krug E, Dahlberg LL, Mercy JA, Zwi AB, Lozano R (ed) 2002. World Report on Violence and Health. Geneva, Switzerland: World Health Organization.

Dehne, K. L. and Riedner, G 200I. "Adolescence - A Dynamic Concept." Reproductive Health Matters 9, (I7): II-I5.

Dilorio, C.; Kelley, M. and Hockenberry-Eaton, M 1999. "Communication about Sexual Issues: Mothers, Fathers, and Friends." Journal of Adolescent health 24, (3): 181-189.

Fatusi, A. O and Blum, W. R 2008. "Predictors of Early Sexual Initiation among a nationally representative sample of Nigerian adolescents." BMC Public Health 8, (136): I-I4.

Fatusi, A. O and Hindin, M. J 20I0. "Adolescents and Youth in Developing Countries: Health and Development Issues in Context." Journal of Adolescence 33, (4): 499-508

Franco, M. L. P. B 2002. "As representações sociais de alunos da $8^{\text {a }}$ série inseridos em oito escolas estaduais do município de São Paulo". Psicologia da Educação I4, (15): I89-205.

Gaskell, G (2004): Entrevistas Individuais e Grupais. In: Bauer, M. W. and Gaskell, G 2004. Pesquisa Qualitativa com Texto, Imagem e Som: um manual prático. Petrópoles: Vozes.

Goss, J. D 1996. "Introduction to Focus Groups." Area 28, (2): II5-123. 
Gowers, S 2005. "Development in Adolescence. Normal Development". The Medicine Publishing Company. Psychiatry 4, (6): 6-9.

Gulamo-Ramos, V.; Bouris, A.; Lee, J.; McCarthy, K.; Michael, S. L.; Pitt-Barnes, S and Dittus, P 2012. "Parental Influence on Adolescent Sexual Risk Behaviors: A Structural Literature Review". Pediatrics I30, (5): I3 |3- I325.

Gupta, N. and Mahy, M 2003. "Adolescent Childbearing in Sub-Saharan Africa: Can Increased Schooling Alone Raise Ages at First Birth?" Demographic Research 8, (4): 93-106.

Hindin, M. J. and Fatusi, A. O 2009. "Adolescent Sexual and Reproductive Health in Developing Countries: An Overview of Trends and Interventions." International Perspectives on Sexual and Reproductive Health 35, (2): 58-62.

Hofstede, G 1980. "Motivation, Leadership, and Organization: Do American Theories Apply Abroad?" Organizational Dynamics 9, (I): 42-63.

Holm, J. and Bowker, J. (ed) 1994. Rites of Passage. London: Pinter Publishers.

Holman, A 2014. How adolescents perceive their Parents Communication about Sex: Toward Reducing Adolescent Sexual Risk. A Dissertation Presented to the Faculty of The Graduate College at the University of Nebraska in Partial Fulfillment of Requirements for the Degree of Doctor of Philosophy.

Instituto Nacional de Estatística (20I0): III Recenseamento Geral da População e Habitação, 2007: resultados definitivos. Maputo, Moçambique: INE.

Instituto Nacional de Estatística (2013): Inquérito Demográfico e de Saúde. Maputo, Moçambique: INE.

Izugbara, C 20I5. "Socio-Demographic Risk factores for Unintended Pregnancy among Unmarried Adolescent Nigerian Girls". South African Family Practice 57, (2): | $2|-| 25$.

Kitzinger, J 1995. "Introduction Focus Groups". British Medical Journal 31 I, (7000): 299-302.

Klingberg-Allvin M.; Tam V. V.; Nga, N. T.; RansjoArvidson, A-B. and Johansson, A. 2007. "Ethics of Justice and Ethics of Care Values and Attitudes among Midwifery Students on Adolescent Sexuality and Abortion in Vietnam and their Implications for Midwifery Education: A Survey by Questionnaire and Interview". International Journal of Nursing Studies 44, (I): 37-46.

Leeming, D. A. (ed.) 2014. Encyclopedia of Psychology and Religion. New York: Springer.

Machungo, F.; Zanconato, G. and Bergström, S 1997.

"Reproductive Characteristics and Post-Abortion Health Consequences in Women Undergoing
Illegal and Legal Abortion in Maputo." Soc Sci Med. 45, (II): I607-1613.

Macleod, C. I. and Tracey, T 2010. "A Decade Later: Follow-up Review of South African Research on the Consequence of and Contributory Factors in Teen-aged Pregnancy." South African Journal of Psychology, 40, (I): |8-3|.

MacPhail, C. and Campbell, C 200I. "I think condoms are good but, I hate those things: condom use among adolescents and young people in a Southern African township." Soc Sci Med. 52, (II): 1613-1627.

Mahy, M. and Gupta, N (2002). Trends and Differentials in Adolescent Reproductive Behavior in Sub-Saharan Africa. DHS, Analytical Studies 3. Calverton: ORC Macro.

Marshall, C. and Rossman, G. B (2006): Designing Qualitative Research. Thousands Oaks: Sage Publication.

McLeory, K. R; Bibeau, D. and Glanz, K 1988. "An Ecological Perspective on Health Promotion Programs". Health Education Quarterly 15, (4): 35I-377.

Meschke, Laurie L.; Bartholomae, S. and Zental, S. R 2000. "Adolescents Sexual and Parent-Adolescent Processes: Promoting Healthy Teen Choices." Family Relations 49, (2): I43-I54.

Miller, K. S and Whitaker, D 200I. "Predictors of Mother-adolescent Discussions about Condoms: Implications for Providers Who Serve Youth" Pediatrics 108, (2): I-7.

Mumah, J; Kabiru, C. W.; Izugbara, Chimaraoke and Mukiira, C (20I4): Coping With Unintended Pregnancies: Narratives from Adolescents in Nairobi's Slums STEP UP Research Report Nairobi: African Population and Health Research Center.

Neto, M. F. and Guimarães, J. A. C 2003. "Crimes na Internet: Elementos para uma reflexão sobre a Ética informacional." R. CEJ 20: 67-73.

Obi, S.N.; Ozuma, B.C. and Onyebuchi, A.K 2002. "Pregnancy in Unmarried Adolescents in Nigeria." International Journal of Gynecology Obstetrics 77 (2): I57-I59.

Ochiogou, I.N.; Miettola, J.; llika, A. L. and Vaskilampi, T 201I. "Impact of Timing of Sexs Education on Teenage Pregnancy in Nigeria: cross-sectional survey of secondary school students." J Community Health 36, (3): 375-380.

Ogunjuyigbe, P.O. and Adepoju, A 2014. "Perspectives on social-cultural context of adolescent reproductive health behavior in Nigeria”. African Population Studies 27 (2): 343351.

Onyeka, I.N., Miettola J., Ilika, A.L. and Vaskilampi, T 201I. "Unintended Pregnancy and Termination of 
Studies among Students in Anambra State, Nigeria: are secondary schools playing their part?" Afr J Reprod Health I5, (I2) I09-I I 5.

Osório, C. and Silva, T. C (2008): Buscando Sentidos. Género e Sexualidade entre Jovens Estudantes do Ensino Secundario, Mocambique. Maputo: WLSA Mocambique.

Oyefara, J. L 2009. "Socio-Economic Consequences of Adolescent Childbearing in Osun State, Nigeria”. KASBI T Business Journal 2, (I\&2): I- 18.

Pratt, C.B and Okigbo, C 2002. "Pregnancy among Kenyan Adolescents: Implication for Social Development". Journal of Development Communication 13, (I): I-14.

Sallis, J. F., Owen, N. and Fisher E. B (2008): Ecological Models of Health Behavior. In K. Glanz, B. K. Rimer, and F. M. Lewis (Eds.). Health Behavior and Health Education: Theory, Research, and Practice. San Francisco: Jossey-Bass.

Saskatchewan Prevention Institute (20I I): Parents as Sexual Health Educators: Literature Review and Environmental Scan.

Segrin, C. and Flora, J (2ed) 20II: Family Communication. New York: Routledge.

Smith, C.P. (2000): Content Analysis and Narrative Analysis. In: Reis, T.E. C.J. (ed) 2000. Handbook of Research Methods in Social and Personality Psychology. Cambridge University Press.

United Nations Development Program (2014): Sustainable Development Goals 2030. Introducing the New Sustainable Development Goals. What's your Goal?

\footnotetext{
i For the purpose of this study, adolescents are those aged 10 to 19 years old.

ii Media center, fact sheet. Update May 2014.

iii Age, education, knowledge

iv Influence of friends and parents, peer pressure

${ }^{\vee}$ Social norms, medias

${ }^{v i}$ Parents form a family which is theoretically defined as

a group of intimates, whose interaction generate a sense
} of home and group identity; complete with strong ties of loyalty and emotions, and experience of a history and future, Segrin \& Flora (201 I).

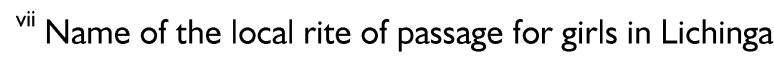

http://aps.journals.ac.za
}

United Nations Population Fund (20/3): Gravidez na Adolescência: Desafios e Respostas de Mocambique. Suplimento do Relatório sobre a populacão Mundial-20I3, Mocambique.

United Nations Population Fund (20|4): The Sate of World Population 2014: Adolescents, Youth and The Transformation of the Future.

Vundle, C.; Maforah, F.; Jewkers, and Rachel; J. E 200I. "Risk for Teenage Pregnancy among Sexually Active Black Adolescents in Cape Town. A case-control study". South African Medical Journal 9I, (I): 73-80.

Weiner, A. and Kulczycki, A (20|4): An Integrated Approach to Targeted, Evidence-Based Livelihood and sexual and reproductive Health Programs for Vulnerable Young People in Fragile States: The Case of Liberia. Pp.307-327.In: Kulczycki, A. (ed) 2014. Critical Issues in Reproductive Health: The Springer on Demographic Methods and Population Analysis 33.

Widman, L.; Choukas-Bradley, S.; Helms, S. W.; Golin, C. E. and Prrinstein, M. J 2014. "Sexual Communication Between Early Adolescents and Their Dating Partner, Parents, and Best Friends." Journal of sex research 5I, (7): 73I-74I.

World Health Organization (20I2): Safe and Unsafe Induced Abortion: Global and Regional Levels in 2008 and trend during 1995-2008.

World Health Organization (20/4): Adolescents: Health Risks and Solutions. Fact sheet N ${ }^{\circ} 345$. Updated May 2014.

\footnotetext{
viii Name given in local language (e-makwa) to the woman/women in charge of initiation rituals
} 